\title{
Ibn Ḥajar al-'Asqalānī's Texts and Contexts: Producing a Sufi Environment in the Cairo Sultanate
}

\author{
Zacharie Mochtari de Pierrepont
}

Aḥmad b. Hajar al-Asqalānī (773-852/1372-1449) was a famous religious scholar and historian, whose reputation in hadīth studies was unparalleled in Cairo at the time of his death. ${ }^{*}$ He stood and was remembered as a man of knowledge, wealth, and influence, both socially and scholarly. Son of a wealthy merchant family on his maternal side and a famous and ancient Shāfīi bayt al-'ilm on his paternal side, he occupied a position of mudarris in various institutions of Cairo and was appointed many times as qādi l-quḍāt of the Shāfici school, for a total of 23 years. His life is relatively well known, mainly due to his fame but also the very extensive biography that his student Muhammad al-Sakhāwī (d. 902/1497) dedicated to him, al-Jawāhir wa-l-durar fı̈ tarjamat shaykh al-islām Ibn Hajar. Ibn Hajar himself wrote his autobiography and gave the list of his mashayikh, and most of the 9 th/15th-century historians of the Cairo Sultanate provided information and biographic notices about him. Modern research also took an interest in this character and at least four academic books have been written in the last decades that deal with Ibn Hajar's life: S. Kawash's Ibn Hajar al-'Asqalānī (1372-1449AD), Ibn Hajar al-'Asqalānì mu'arrikh by K. 'Izz al-Dīn, The life and works of Ibn Hajar al-Asqalānī by Aftab A. Raḥmānī, mostly an organized compendium of al-Sakhāwī's Jawāhir, and Ibn Hajar by R. Kevin Jacques. Thus, when it comes to his personal life, his writings, his institutional positions and his travels, we comparatively know a lot about him. It should not come as a surprise, since Ibn Hajar was remembered as one of the greatest Islamic scholars of his time, due mainly to his involvement in hadith studies and, among many works, his famous commentary on the Șaḥ̄h al-Bukhārī, the Fatḥ al-bārī. Nevertheless, many things are still unknown

* This article has been finalized within the context of the project "The Mamlukisation of the Mamluk Sultanate II: Historiography, political order and state formation in fifteenth-century Egypt and Syria" (Univeristy of Gent, 2017-21); this project has received funding from the European Research Council (ERC) under the European Union's Horizon 2020 research and innovation programme (Consolidator Grant agreement No 681510). 
about this author, not in the least concerning the position of his historiographical writings. This will be the focus of this chapter. Despite the fact that studies by J. Blecher, ${ }^{1}$ Muhammad Gharaibeh, ${ }^{2}$ and Anne F. Broadbridge ${ }^{3}$ have recently tackled some issues linked to Ibn Hajar's life, career, competitive environment, and historiographical writings, a lot of work remains to be done in this respect.

This paper aims to engage in a discussion about some features of Ibn Hajar's writing of history and the way he shaped new narratives in his last historiographical work, the Inbä'al-ghumr bi abnä al-umr. It draws special attention to how historiographical works should be seen as coherent systems of meanings and understood in their own discursive contextual framework. As part of an ongoing broader study of Ibn Hajar's historiographical works, my main focus will be to understand, in particular, how Ibn Hajar addresses some part of the Sufi environment of the Cairo Sultanate. It is my goal to engage a discussion about how a specific sociopolitical historiographical space was created in the Inb $\bar{a}^{2}$ al-ghumr against the wider background of the alleged siyassa-orientation of the period's historiographical production. ${ }^{4}$ It will be argued that in this distinct space, Sufism and Sufi characters were presented to inform about the dynamics of power and the social order that were crafted in the Inb $\vec{a}^{3}$ and that were arguably the main underlying theme of this chronicle.

\section{$1 \quad$ General Framework}

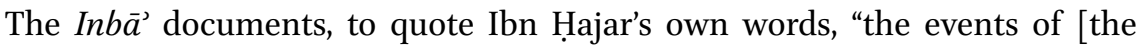
author's] life time since [his] birth in the year 773 [1372] and so on, separating for every year the situations of the duwal from the obituaries of the a'yān." It is introduced as a continuation of Ibn al-Kathïr's Ta'rïk $h^{5}$ and claims to draw mainly from Ibn Hajar's testimony of what he personally witnessed (shähadtu$h u$ ) and heard from trustful people and some previous historians of the period. ${ }^{6}$ Ibn Hajar started to work on the Inb $\bar{a}^{3}$ in the year $836 / 1432$, but it was only completed in 850/1446. With the Fath al-Bārí, the Inb $\bar{a}^{3}$ may have been the work Ibn Hajar spent the most time working on. It covers a period between the years $773 / 1372$ and $850 / 1446$ and is organized as an annalistic chronicle. Each year is

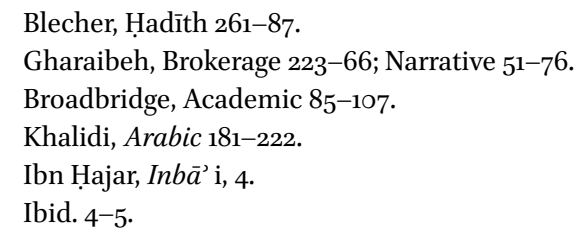


separated in hawädith and wafayāt sections. The wafayāt, the parts of the work that will be most discussed here, document a wide range of people from various backgrounds and positions and do not consider special social, political, or institutional categories, unlike what had been the case with other biographical writings of Ibn Hajar, such as his Lìsān al-Mìzān, which was written 40 years before $^{7}$ and focused exclusively on the muhaddithin. ${ }^{8}$

The historical context in which Ibn Hajar wrote the Inb $\bar{a}$ also gradually evolved in the course of its writing. But, as a hypothesis, it would have made sense for the author to be more careful when he completed his work, to suit the audience of the late 840 / $/ 1440$ os better, and when he considered his chronicle achieved. Being the last historiographical piece produced by Ibn Hajar, the Inb $\bar{a}^{\prime}$ also illustrates the last efforts of this scholar to engage in a new historiographical production, just a few years after he had completed his history of the quḍāt of Egypt in the Raf' al- ișr 'an qud̄àt Mișr. ${ }^{9}$ It is thus most closely intertwined with al-Zāhir Jaqmaq's rule (841-57/1438-53), at a time when the author was still politically engaged and active. In the last years of the redaction of the Inb $\bar{a}^{2}$, Ibn Hajar was actually trying to regain his prestigious position as shaykh of the Sufi Khānqāh al-Baybarsiyya in Cairo, a position he had held without interruption for 30 years and lost in 849/1445 after a confrontation with Sultan Jaqmaq..$^{10}$

In this respect, the political and cultural dynamics at the end of al-Zāhir Jaqmaq's reign are of crucial concern to better understand the Inb $\vec{a}$. Although poorly known, it seems this period was marked by a renewal of asceticism and exterior signs of extreme piety. ${ }^{11}$ Some elements tend to show that the political influence of prominent members of the Sufi community, especially tenants of the monistic doctrine, was dwindling. More generally, mentions of Sufism and the number of Sufi characters decrease strongly during the narratives of the Inb $\bar{a}^{\prime}$ concerning al-Z̄āhir Jaqmaq's period; no Sufi zāwiya is mentioned for this period. Only six characters are explicitly designated as Sufis among the characters of the wafayāt in the first years of the sultan's reign, and none after that. This discrepancy does not mean, of course, that no prominent Sufi characters died during Jaqmaq's rule. It either underlines the weakening of Sufi shuyükh in the dynamics of power, their decrease in political influence, or Ibn Hajar's disinterest in Sufi scholars between 842/1438 and 848/1451.

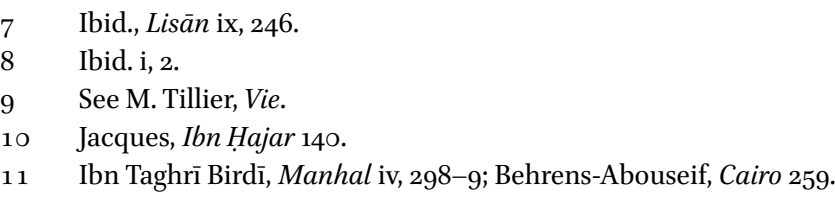




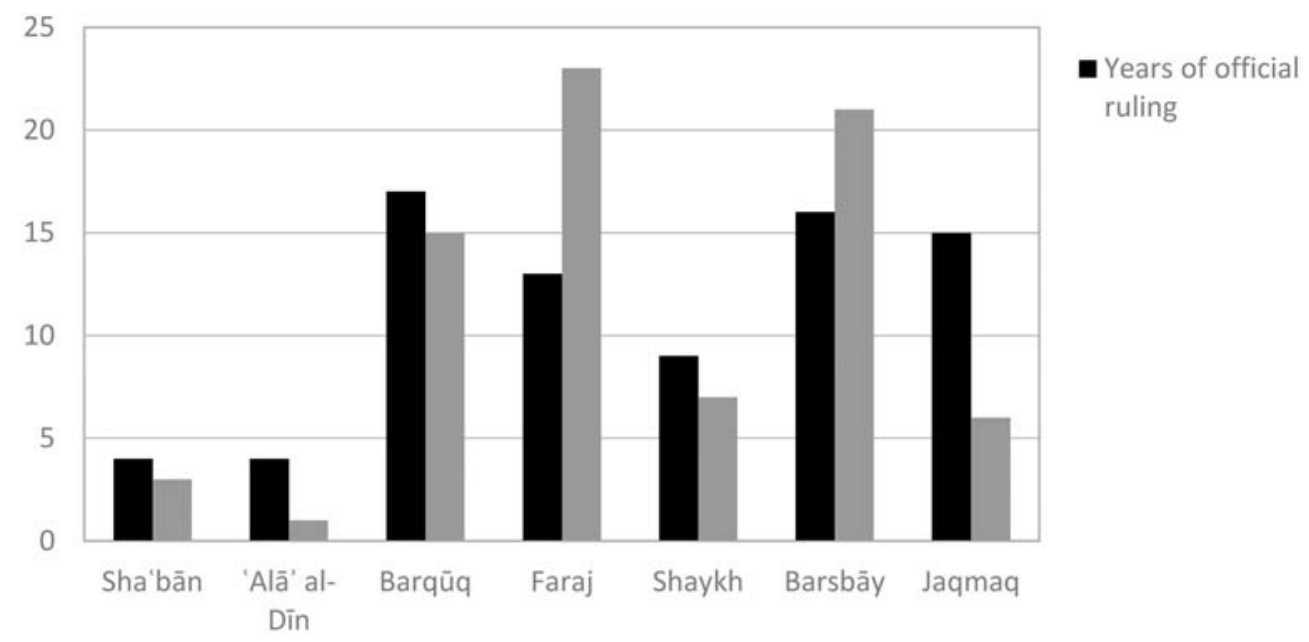

FIGURE 7.1 Number of explicit references to Sufis during each reign covered by the Inb $\bar{a}^{\prime}$

In any case, their disappearance from the Inb $\vec{a}$ is testimony of the different environment in which the last annals of Ibn Hajar's chronicle were written. A few years before, Ibn Hajar's authorial choices may have been very different under al-Ashraf Barsbāy, a strong supporter of the Sufi environment and a man personally engaged in the patronage and company of Sufis. ${ }^{12}$

It will be argued here that the Inb $\bar{a}^{3}$ must be contextualized and understood in these specific frameworks of both Ibn Hajar's personal situation and the broader context of the $840 \mathrm{os} / 144 \mathrm{O}$. These informed the agency and intentionality of its author ${ }^{13}$ and left a deep impression on how he wrote his chronicle. For that reason, it also seems very useful to draw comparative examples from the Durar al-kämina and the Dhayl al-durar, two of Ibn Hajar's biographical dictionaries written before Sultan al-Z̄āhir Jaqmaq's rule. The Durar al-Kämina focused on 8th/14th-century characters and was completed in 837/1427, while the Dhayl al-durar al-kämina was completed in 832/1429 and covered the years 8o1-32/1398-1429. ${ }^{14}$ The contents of the Inbä thus overlap with each of these works for almost three decades, which allows us to study the attentive rethinking and rewriting of the same events and characters' lives by the same author within an evolving historical context from the early 830s/1430s to the late $8405 / 1440$ os. Here, I will argue that the precise recontextualization of each of these works is indispensable to understanding Ibn Hajar's historiographical

\footnotetext{
12 Ibn Ḥajar, Inbā' iii, 72; Behrens-Abouseif, Cairo, 253.

13 See Hirshler, Medieval 1-16.

14 'Izz al-Dīn, Ibn Ḧajar 273, 282.
} 
accounts and that Ibn Hajar's historical stance, on any subject, should only be understood as a temporary and contextually embedded position. For, as remarked recently by Muhammad Gharaibeh about the Lisān al-mizzān and the Durar al-kämina, Ibn Ḥajar was creating with the Inb $\bar{a}$ new historical narratives, rather than merely reorganizing them. ${ }^{15}$ Although, as biographical dictionaries, the Dhayl al-durar and the Durar certainly did not entirely serve the same ideological and historiographical purposes, they shared a lot of biographical data. The careful modification in the Inb $\bar{a}^{3}$ of many previous accounts, therefore, reflects new discursive strategies serving new purposes.

All in all, it seems that the depiction of Sufi characters in the Inb $\bar{a}^{3}$ reflects three main layers of discursive construction regarding Sufis and their place in history, each of which will be discussed in more detail below. First, their presentation gives an account of Ibn Hajar's personal stance on various matters linked to Sufism. Second, Ibn Hajar represented Sufi characters in the more general changing political context of the 83os-40s/1430s-40s, taking gradual notice of the new environment in which the ruling elites were producing and reproducing themselves, ${ }^{16}$ not because Sufism as a whole was withdrawing from the political sphere but because new groups emerged from the constant and changing struggles of power, influence, and ideology in which Sufis were also taking part. Finally, Ibn Hajar was shaping the moral, political, and social boundaries in which Sufi characters were deemed to have a positive role in the Cairo Sultanate. In other words, social order, produced through Ibn Ḥajar's discursive agency, seems to have been the recurrent and main pattern of the Inb $\bar{a}^{\text {' }}$ al-Ghumr, in which the dynamics surrounding the dawla - the specific configuration of the sultanate's power elites and practices-and its main related protagonists played a central role. ${ }^{17}$ Sufi characters obviously had their part in this social and narrative order, like all actors in his chronicle. Ibn Hajar engaged in delimiting this role and fixing boundaries in the framework of the social, cultural, and political environment of the 9 th/14th century Cairo Sultanate.

As will be demonstrated below, the place of Sufis and Sufi institutions were integrated in narrative strategies that were part of the broader historiographical construction Ibn Hajar was erecting. A better understanding of that particular place allows, therefore, one to better grasp that historiographical architecture.

\footnotetext{
15 Gharaibeh, Narrative, 72.

16 Van Steenbergen, Mamlukisation 35-7.

17 Van Steenbergen, Mamlukisation 20-1; Appearance 74.
} 
As far as Ibn Hajar's historiographical works are concerned, their Sufi environment has never attracted much interest among scholars and academics. This makes perfect sense, since Ibn Ḥajar trained as a Shāfīi scholar and a muhaddith and was renowned for his work on hadìth science. At no moment in time was he ever considered a Sufi shaykh, nor did he show a strong or specific interest for Sufi-related cultural production in his many writings.

Thus, Sufism seems to have been marginal in Ibn Hajar's career, and this marginality is reflected in the Inba al-ghumr, a political chronicle mainly interested in the dynamics of power in the Cairo Sultanate and the competitive sociopolitical environment in which the author grew up and struggled. Yet, like most scholars of his time, Ibn Hajar was certainly aware of Sufi practices and teachings. It even looks very likely that he was much more informed about it than most of his contemporary scholars, who engaged primarily in traditionalist knowledge. Even without taking into consideration later claims that he had received a Sufi khirqa, ${ }^{18}$ he had still trained as a young scholar with prestigious Sufi masters of his time and spent more than a year in Zabìd. At this time, Ibn 'Arabỉ's widespread and contested doctrines of monistic Sufism (alittihād) were triumphant in the Tihāmi metropolis. ${ }^{19}$ For more than 3 o years, he was also at the head of the Khānqāh al-Baybarsiyya al-Jashnakīriyya in Cairo, one of the largest Sufi institutions of the Cairo Sultanate, which provided him with important means to build his clientele and career, including from among the Cairo Sufi community.

But, whatever the personal involvement of Ibn Hajar in his Sufi environment was, and despite the comparatively peripheral feature of Sufism in the Inb $\vec{a}^{3}$, he did dedicate a number of his chronicle's wafayāt to Sufi characters. As such, this work does participate in informing and shaping a discursive perception of Sufi communities during the first half of the 9 th $/ 15$ th century. It deserves all the more attention as Ibn Hajar's chronicle is taken as one of the historiographical frames of reference in the field of 9 th $/ 15$ th-medieval Islamic history.

To underline the evolution of specific narratives concerning Sufism in changing contexts and to emphasize the carefully built discourses embedded in the personal, political, cultural, and social life of the 9 th $/ 15^{\text {th }}$ century as represented in Ibn Hajar's historical writings, we have mainly used prosopographical data, tracing all characters referred to as Sufis, either explicitly or impli-

18 Geoffroy, Soufisme 364 .

19 Knysh, Ibn Arabî 227; Mochtari de Pierrepont, Espaces i, 208, 214. 
citly (shaykhs of zāwiya, people having followed the tariqa of Sufi masters, those linked to a țấifa, etc.). These references are widespread in the Inb $\vec{a}$ alghumr, as they are in most historical chronicles of the time. They illustrate the implementation of a historiographical frame that was consciously chosen by the author. This type of data survey obviously has its limits, since it does not take into account all characters that were engaged in Sufi practices nor can it entirely appreciate the various vocabularies implicitly referring to Sufism. Yet, these references, considered within the whole historiographical framework of the In $b \vec{a}$, underline how some specific narrative choices were made by Ibn Hajar concerning various topics and figures. The regular absence of these explicit references also stresses narrative gaps, suggesting that, in many cases, the author consciously chose not to refer to the Sufi affiliation of some 'ulama', thus shaping them into a distinct historical memory.

By using a precise wording for qualifying individuals, Ibn Hajar allows the reader to connect specific individuals to the Sufi path; that is, individuals who "claimed, contested, embraced ... the traditions associated with tașawwuf (Sufism)" and were identified as doing so. ${ }^{20}$ This precision should be relevant to us since it was relevant for the author. Thus, on the one side, Muhammad al-Kāzrūnī, nicknamed al-Ṣūfì (d. 776/1375), ${ }^{21}$ or Muhammad al-Dimashqī (d. 809/1407), described as a "Sufi of the khānqāh Sa'ìd al-Su'adā,", 22 to give but two examples, are presented in a way that shed light on their affiliation with Sufism. Even though the author often did not expand on the nature of their affiliation and degree of involvement, both in a personal mystical path and a shared collective experience, the latter was a cornerstone in the historiographical display of Sufism, as already emphasized by Nathan Hofer. ${ }^{23}$ Such presentations seem equivocal and intersect with various meanings of an individual's commitment to the Sufi path. It is not particularly original, and we find the same kind of designations in many other sources throughout the period. But it is of interest to consider this as part of Ibn Hajar's own historiographical choices because it informs us of his narrative construction and influences.

Differences in status, standing, and involvement in tașawwuf were actually expressed through the formal construction of each tarjama in the wafayat, and they meant something specific to their audiences of readers. The formal structure of a tarjama often gives by itself a hierarchy of information concerning the involvement of the subject in tașawwuf and hints at how to understand

\footnotetext{
$20 \quad$ N. Hofer, Popularisation 4.

21 Ibn Hajar, Inbä' i, 49.

22 Ibid. ii, 335.

23 N. Hofer, Popularisation 5.
} 
the role and moral pretension of each tarjama in the broader text's intertextuality. It indeed leaves little doubt that Ibrāhīm al-Mulaqqin (d. 799/1397), a very popular Sufi master and famous preacher (wāiz) of Damascus, ${ }^{24}$ may not have been seen as connected to tașawwuf in the same way as Muhammad al-'Ajamī (d. 815/1412), a former soldier who took the wool $(a l-s u \bar{u} f) .{ }^{25}$ The retirement as a Sufi of Muhammad al-Ajamī was mentioned at the end of his notice and preceded his death's mention, while the status of Ibrāhīm al-Mulaqqin as Sufi was stated in the introductory part of his notice. The same could be said for most great Sufi masters mentioned in the Inb $\vec{a}$ : The skilful Sufi elites versed in the teaching and practices of tașawwuf, with a number of followers and their own private majlis, are often identified in the tarjama's introduction, with the main body of their notice dedicated to their activities as Sufis.

The questions that we now wish to turn to are the following: What was the role of those explicitly identified as Sufis in the larger narrative and metatextuality that Ibn Hajar was slowly carving out? What did his choices to identify them as Sufis imply for the discursive efficiency and goals of the Inb $\vec{a}$, mostly concerned with shaping the social and political narrative of the Cairo Sultanate? Not only will I argue that these choices underline the very careful selection of wording and narratives by which Ibn Hajar constructed the Inb $\bar{a}$, they also identify the moral and social boundaries that he set in his discursive constructions and that give life to a Sufi environment that was only crafted as such in the Inbä' itself.

Characters explicitly designed as or strongly linked to Sufism in the Inb $\vec{a}$ form a small group: 131 figures are either said to be Sufis, to be learned in tașawwuf, to follow a Suf tariqa, to be a member of a $z \bar{a} w i y a$, or to wear a Sufi nisba. ${ }^{26}$ The Shādhiliyya is by far the most represented tariqa of the $\operatorname{Inb} \bar{a}^{\prime}(12) \cdot{ }^{27}$ Most of the other turuq only have between one and five members who are introduced in the chronicle. ${ }^{28}$ Only one reference is made to the great shaykh Aḥmad al-Badawī

\footnotetext{
24 Ibn Ḥajar, Inb $\bar{a}^{\prime}$ i, 53 .

25 Ibid. ii, 533 .

26 These numbers come from a census of the terms șūf șufi, tașawwuf, zāwiya, and zawāaya . We have also looked for the most common țuruq in the Cairo Sultanate and their nisbas: al-Shādhiliyya, al-Wafāciyya, al-Aḥmadiyya, al-Qādiriyya, and al-Suhrawardiyya.

$27 \quad$ Not counting the members of the Wafāiiyya.

28 Five for the Mawșiliyya, three for the Rifāiiyya, five for the Suhrawardiyya, especially via
} 
(d. $675 / 1276)^{29}$ and one mention of the Ahmadiyya path, ${ }^{30}$ which may emphasize the decrease of this tariqa's influence among the political elite from the last quarter of the 8th/14th century onward. It seems then that the Inba $\vec{a}^{3}$ corroborates C. Petry's claim that "references to Ṣūis in general greatly outnumbered specific citation in either order."31 These numbers in the Inb $\vec{a}^{\prime}$ do not claim comprehensiveness, especially since some protagonists of the Inb $\vec{a}^{3}$ are presented without being explicitly referred to as members of a Sufi tariqa $a$, like the famous Suhrawardī shaykh Muhammad b. 'Umar al-Ghamrī (d. 849/1446). ${ }^{32}$ Yet, they attest to Ibn Hajar's specific representation and presentation of the main Sufi paths in his environment and the political dynamics of the sultanate. In this narrative representation, important Sufi masters of the Suhrawardiyya, like Ahmad al-Zāhid (d. 819/1416) or Madyan (d. 861/1458), do not appear in the Inb $\bar{a}$, nor does Muhammad b. Hasan al-Ḥanafì (847/1443) appear as a Sufi master. ${ }^{33}$ Yet, he was a prominent Shādhilī shaykh and a personal acquaintance and comrade of the author. ${ }^{34}$ His spiritual successor, Ahmad al-Sarasī, had also studied with Ibn Hajar. ${ }^{35}$ These characters, because they were not referred to as Sufis, were not included in our data.

Most of the Sufi characters in the dataset thus identified in Ibn Hajar's In $b \vec{a}^{\prime}$ al-ghumr come from the Syro-Egyptian territory, mainly Damascus, Jerusalem, and Cairo, although other regions are also mentioned. Yemeni Sufis (seven) also occupy some substantial narrative space, which may be due to Ibn Ḥajar's past riḥlas in the Rasūlid Sultanate. Mecca, the Hijāz, and the Upper-Egyptian Șaîd region seem in this regard very distant. This actually appears to be a general feature of the Inba $\bar{a}$ s inclusion of scholars and does not specifically concern Sufi characters. Sufis in the chronicle do not only represent the Sufi elites in terms of social position and power, although the Sufi elites are well introduced, with a number of zäwiya and ribät shaykhs (28), holders of a mashyakha in a khānqāh (5), and shaykhs of a tarīqa (4). Four of them are engaged on the Sufi path after retiring from the court or the army. Most are 'ulam $\bar{a}$ ' and represent

the shaykh Yūsuf al-Kūrānī al-'Ajamī (d. 768/1368), two for the Qādiriyya, one for the Șamādiyya (Ibn Ḥajar, Inbä’ iii, 287), stemming from the Qādiriyya. No characters belonging to the Ahmadiyya are mentioned, although its fuqarä' are linked to an amir (ibid. ii, 35). We have not included the members of the Hurüfiyya (ibid. iv, 10o).

29 Ibid. iii, 103. On this figure, see Mayeur-Jaouen, Sayyid.

$30 \quad$ Ibn Ḥajar, Inb $\bar{a}^{\prime}$ ii, 35 .

31 Ibid. iv, 243.

32 Petry, Civilian 270.

33 Ibn Ḥajar, Inbā’ iii, 268. On this Sufi master, see Sha'rānī, Ṭabaqāt ii, 135-62.

34 Geoffroy, Soufisme 23.

35 Sakhāwī, Jawāhir iii, 1176. 
the common type of al-'âlim al-șüfı́ distinguished by É. Geoffroy:36 "scholars with a strong formation in exoteric religious sciences, either one who came on the mystical path during his youth," while learning sharĩa, or one who later "converted" when of "mature years, after becoming a religious notable holding various manșab-s." 37 As established scholars, these characters often had extensive relationships with the ahl al-dawla, but only some of them were part of the sultanate's institutions of administration and justice (with four qudāt). Some, then, engaged in a scholarly and administrative career in which Sufism appeared as one religious skill and practice among others. Yet, they were still a minority, which underlines that Ibn Hajar was not particularly concerned to emphasize the involvement of Sufis in the sultanate's apparatus of power.

A little more than a quarter of these figures (34) were linked at some moment in their life to a $z \bar{a} w i y a$. The term zäwiya appears 48 times in the chronicle, and these institutions are mostly located outside Cairo. If we add to that mentions of khānqāhs (98), ${ }^{38}$ Sufi institutions seem to have been a true concern for the author, although most frequencies concerning khānqāhs are linked to holders of the mashyakhas, with only some of them identified in the text with a personal practice of tașawwuf. While it would be quite difficult to define any systematic characteristic of Sufis in the Inba al al-ghumr, being a member of a $z \bar{a} w i y a$, having built a $z \bar{a} w i y a$, or having established oneself as a shaykh of a $z \bar{a} w i y a$ is one of the inevitably features mentioned in Ibn Hajar's work regarding Sufi characters.

Some distinct Sufi groups seem to appear in the Inb $\bar{a}$, although the number of Sufi characters is far too low, by itself, to be representative of any specific network beyond the small primary circle of a shaykh and his main disciples. Yet, because of the generally small degree of information about Sufi characters in the Inb $\vec{a}$, the presence of some contemporary masters strikes the eye. This is the case of Yūsuf al-Ajamī (d. 768/1367) ${ }^{39}$ and Abū Bakr al-Mawșilī (d. 797/1394), two tariqa shaykhs of the 8th/14th century whose influence was still felt in the first half of the 9th/15th century. They are linked to 15 members of the Sufi community, and 30 textual references are somehow related to them, framing them among the main protagonists of the Sufi environment introduced in the $\operatorname{In} b \vec{a}$.

\footnotetext{
36 Geoffroy, Soufisme 126-34.

37 Ibid. 126 .

38 The number of mentions was collected using Lexico 3 , a software for lexicometric analysis, looking for the most common forms of reference in the Inb $\bar{a}$ : al-zāwiya, bi-zāwiya, $z \bar{a} w i y a$, and zawāy $\bar{a}$. The same pattern was applied for the khānqāhs.

See Ibn Ḥajar, Durar iv, 286 (n. 5247); Maqrīzì, Sulūk iv, 310.
} 
These general and broad features underline that some part of the narrative framework of the In $b \vec{a}$, regarding its Sufi environment, was shaped differently from Ibn Hajar's previous works. This follows from the fact that Sufi characters presented in the $I n b \bar{a}$ are not necessarily the same ones that feature in the previous historiographical works of Ibn Hajar. Some Sufi figures mentioned in the Durar al-kämina and the Dhayl are thus not introduced in the Inb $\vec{a}$. This is, for example, the case of Aḥmad b. 'Abd al-Raḥmān al-Qalānisī (d. 773/1372) and Shihāb al-Dīn Ahmad b. Iskandar al-Husaynī (d. 777/1375). ${ }^{40}$ In the same way, some Sufi characters of the Inbā', like 'Alī b. 'Abd al-Qādir al-Marāghī, Muhammad al-Kurdī (d. 788/1386), or Khalīl al-Janadī (d. 813/1410), are not found either in the Durar or the Dhayl al-durar. ${ }^{41}$

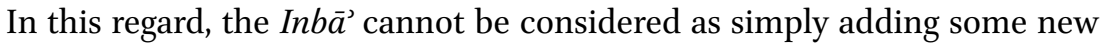
information after having extracted previous entries from Ibn Hajar's own works. The author relieved his chronicle of characters he deemed now useless or irrelevant in the more general framework of the Inb $\vec{a}$. This implies different discursive goals for these works. It also implies the shaping of new narratives better fitting the chronicle's purpose. At an interpretive level, it means it is not possible to correlate the narrative of a character in Ibn Hajar's historiographical works without referring to the precise context of the writing of such a reference. One must then adopt a diachronic perspective corresponding to different moments of Ibn Ḥajar's life, social and political environment, and authorial personality, in which particular historiographies were shaped.

The Inb $\bar{a}^{3}$ was also particularly interested in the relations between prominent figures of the dawla and members of the Cairo Sultanate's different communities. The Sufis are no exception, and many Sufis presented in the chronicle were indeed linked to the ruling elites. It underlines that, in some ways, Ibn Hajar was mostly concerned with the elites of the scholarly environment. Yet, the interaction between Sufis and the dawla, by itself, was not a preoccupation of the author. As mentioned, only a minority of the Sufis presented in the chronicle were indeed holders of sultanic offices. Moreover, Ibn Hajar does not seem particularly preoccupied with Sufis of khānqāhs, the most clearly endowed religious institutions linked to the sultanic office. ${ }^{42}$ While addressing the khānqāhs, it is almost only the holders of mashyakhas in which Ibn Hajar is interested, many of whom did not have a Sufi background. It is then mainly in relation to the careers and success of Sufis, the competitive environment in

$40 \quad$ Ibn Ḥajar, Durar i, 118 (n. 284); v, 245 (n. 1337).

41 Ibn Ḥajar, Inb $\bar{a}^{\prime}$ i, 325; ii, 129, 470.

42 See on this question Hofer, Popularisation $35^{-8}$ o. 
which they were evolving, and their place and role in the politics of the sultanate that Ibn Hajar mentioned the links between the Sufi religious elites and the political ones. Such mentions were social and symbolic markers attached to scholars. They were part of delimiting and contextualizing a normative expression of scholarly behaviors and patterns inside the framework and boundaries of the society Ibn Hajar was shaping. This implied, from the author, a change in narratives in relation to new contexts.

\section{Narrative Changes and Discursive Transformations: Crafting New Meanings}

Narrative changes can be particularly emphasized comparing some of Ibn Hajar's notices in various works. Recently, M. Gharaibeh presented a case study that also reflected this idea, addressing specific patterns Ibn Hajar used to shape different images of the muhaddith Mughulțāy and considering various narrative strategies developed for the same character both in the Durar alkāmina and the Lissān al-Mīzān.43 Although M. Gharaibeh did not elaborate on the two very different temporal contexts-almost 30 years separate these two works, corresponding to two very different moments in Ibn Hajar's career and the sociopolitical environment of the Cairo Sultanate-he clearly underlined the author's specific discursive strategies that shaped Mughultạy's figure in a way that fit Ibn Hajar's narrative and scholarly goals. ${ }^{44}$ Indeed, changes in the Inb $\bar{a}^{3}$ narratives, compared to previous works of Ibn Hajar, are a striking feature of this work, too. All this highlights the importance of contextualization, in which the author set himself to rewriting some previous narratives. ${ }^{45} \mathrm{~A}$ good illustration can be found in how Ibn Ḥajar refers to Ibn 'Arabì's Sufi teachings, since it was a point of intellectual and social contention in Cairo in his times.

\subsection{Aḥmad b. al-Raddād and Ibn Arabī: Two Adjusted Narratives}

Ibn Ḥajar's position vis-à-vis Ibn 'Arabī has already been approached in Alexander Knysh's brilliant work Ibn Arabì in the later Islamic tradition. ${ }^{46} \mathrm{He}$ pointed out that Ibn Hajar conserved through his works an indecisive standing regarding the shaykh himself, "avoiding a clear-cut judgement of heresy or unbelief"

\footnotetext{
43 Gharaibeh, Narrative $59-65$.

44 Ibid. 72.

45 An aspect that does not only concern Sufi figures, but that we will only illustrate here with Sufi characters due to the specific goals of this paper.

46 Knysh, Ibn 'Arabi 128-30.
} 
but being "much more mistrustful of Ibn 'Arabīs followers." ${ }^{\text {"7 }}$ While conserving an "elusive"48 position regarding the shaykh al-akbar, a few references in the

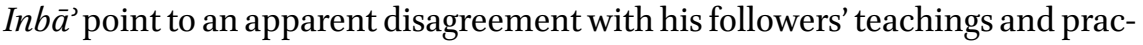
tices, criticisms he had already stated softly long before in the Lisānn al-Mizzān. ${ }^{49}$ In the Inba , Ibn Hajar makes a stronger claim, a position particularly noticeable in the tarjama of Ahmad b. al-Raddād (d. 821/1419).

Ahmad b. al-Raddād al-Qurashī (d. 821/1419) was one of the prominent Sufi shaykhs of Rasūlid Yemen at the beginning of the 9 th/15th century, and his biographical notice in the Inba $\vec{a}^{3}$ is all the more relevant since he was a scholar the author had personally met during his Yemeni rihla.$^{50}$ But he was not only an important scholar close to the Rasūlid sultans al-Ashraf Ismāîl (r. $77^{-}$ 8o3/1377-1401) and al-Nāṣir Ahmad (778-8o3/1377-1424), he was also a friend and associate of the qāḍ̂̀ l-quḍāt of Yemen, Majd al-Dīn al-Fīrūzābādī, Ibn Hajar's own master of linguistics and grammar, in whose teachings Ibn Hajar always took great pride. ${ }^{51}$ If we are to believe Ibn Ḥajar, al-Fīrūzābādī's advice led the Rasūlid sultan al-Nāșir Aḥmad to name Ibn al-Raddād qā dì l-quḍāt after the death of the latter. ${ }^{52} \mathrm{Al}-\mathrm{Na} s ̦ i$ ir Ahmad also married a woman from Ibn al-Raddād's house, ${ }^{53}$ consequently reinforcing his alliance with the powerful Tihāmi tribe of the Qurashiyyūn, among whom Ibn al-Raddād ranked highly. ${ }^{54}$ Thus, although Ibn al-Raddād was mainly presented by Ibn Hajar through the prism of Sufism, Ibn 'Arabī's doctrines, and his companionship with al-Nāṣir, he was, in fact, one of the most powerful Yemeni figures at the beginning of the 9th/15th century. In the Inb $\bar{a}^{3}$, Ibn Hajar's obituary of this character states:

Aḥmad b. Abī Bakr b. Muḥammad b. al-Raddād, al-Makkī, al-Zabīdī alșūfit, the qāọī Shihāb al-Dīn al-Shāfi'ì, was born in 740 [1340], and entered Yemen, where he joined the company of the sultan al-Ashraf b. al-Afdal and he remained with him. He became a boon companion [of the sultan]

47 Ibid. 128-9.

48 Ibid. 128.

49 Ibn Ḥajar, Lisān vii, 392, 396 (n. 7229). Also quoted in Knysh, Ibn Arabi 129.

50 Sakhāwī, Jawāhir iii, 1074 .

$5^{1} \quad$ Ibn Ḥajar, Raf' 63 ; Dhayl ${ }_{176-7}$ (n. 437).

52 Ibid. Inbä' iii, 178. Also quoted in Knysh, Ibn 'Arabi 249. This claim by Ibn Hajar is highly dubious: No Yemeni sources seem to mention it, and Ibn al-Raddād's influence at the court had been very strong long before al-Fīrūzābādì's death. Ibn Ḥajar may have made this claim to amplify both the influence of his master al-Fīrūzābādī and Ibn al-Raddād's later supposed theological errors.

53 Burayhī, Țabaqāt 299.

54 Mochtari de Pierrepont, Espaces i, 214, 216. 
before getting very close to him. He had many merits as a poet and a clever prose writer, although he had too much fondness for the temporal love and tendencies toward philosophical Sufism ... and he composed much poetry and prose in which he propagated [the] manifest delusion [of Ibn 'Arabī's teachings] until he completely corrupted the faith of the inhabitants of Zabìd, except those God deemed not to. ${ }^{55}$

The position of Ibn Hajar regarding Ibn 'Arabī's followers seems to be pretty clear: Ibn al-Raddād overstepped the boundaries of decency and orthodoxy. References to "corruption" ( fasa $\bar{a}$ ) and those spared by the Divine might also be a direct hint at the chaos that followed in Zabild in the years following Ibn al-Raddād's death and, particularly, that of his companion and son-in-law, the Rasūlid sultan al-Malik al-Nāṣir Aḥmad (r. 803-27/1401-24). Yet, almost 20 years before the $\operatorname{In} b \bar{a}$ ' was completed, Ibn al-Raddād's biographical notice in the Dhayl al-durar al-kämina presented this character in quite a different light:

Aḥmad b. Abī Bakr b. Muḥammad b. al-Raddād, al-Makkī, Shihāb al-Dīn, Abū l-Abbās al-șüfí. He entered Zabīd and he engaged in tașawwuf. He became a companion of Ismāîl al-Jabartī, ${ }^{56}$ propagator of Ibn 'Arabī's [teachings], and he specialized in it. He versified them in long poems. He became a boon companion to [the sultan] al-Malik al-Ashraf and then [al-Malik] al-Nāșir [Ahmad]. He was [a man of] merits, worshiping and intelligent. He received the [office of chief judge] at the end of his life. I heard of his compositions and good deeds. He died in Dhū al-Qacda [of the year 821$] .57$

This previous account of Ibn al-Raddād is clearly more positive. Ibn al-Raddād was presented stripped of misgivings. His penchant toward Ibn 'Arabī's thesis was not linked to some kind of corruption that hit Zabid's inhabitants. Of course, in 832/1428-9, when Ibn Hajar wrote the Dhayl al-durar, the plague, war, and looting had not yet struck the Tihāmi metropolis ${ }^{58}$ nor did the Rasūlid dynasty stand on the verge of collapsing. Yet, Ibn Hajar did not elaborate on the Inb $\bar{a}$ 's account focusing on the Yemeni turmoil of the 840s/1440s, but on Ibn

55 The last sentence is quoted in Knysh, Ibn 'Arabi 248, 378. See Ibn Hajar, Inbä' iii, 178.

56 The shaykh al-shuyūkh of Zabīd's Sufis and a close companion of the Rasūlid sultan alAshraf Ismāīil.

57 Ibn Ḥajar, Dhayl 200 (n. 50o).

58 Ibn al-Dayba', Qurrat 403; Bughyat 112; Vallet, L'Arabie 679-80; Mochtari de Pierrepont, Espaces i, 66. 
'Arabī's followers' dangerous stance that supposedly led the Zabīdī community to its doom. This narrative choice underlines that he addressed this notice for the Cairo Sultanate's audience. Indeed, since the 840 o/ 1440 , the struggle of Ibn 'Arabi's doctrine had winded down in Yemen, following the political decline of Ibn 'Arabī's followers. ${ }^{59}$ Yemeni accounts of Ibn al-Raddād also do not only focus on this character's stance concerning Ibn 'Arabī, being equally interested in the social and political environment of the master. ${ }^{60}$ It seems Ibn Hajar's own social and political environment had changed between the composition of the Dhayl and the Inb $\bar{a}^{3}$, or his personal opinion had evolved. In any event, Ibn Hajar's statement in the Inb $\vec{a}^{\text {? }}$ could not be used to justify by itself Ibn Ḥajar's general position about Ibn 'Arabī's followers or Ibn al-Raddād. Therefore, it seems that Ibn Hajar's position and narration of this particular topic depends on the work referring to it and the context in which it would have been shaped. Thus, Ibn al-Raddād's notice can only be inscribed in the specific framework in which the Inb $\vec{a}^{3}$ or the Dhayl were written, reflecting two different discursive constructions at two moments of Ibn Ḥajar's historiographical strategies.

Because, taken on its own, Ibn al-Raddād's notice in the Inb $\bar{a}^{3}$ brings only scant information on the character himself, this tarjama may also be more interesting, considering the broader context of the work in regard to conflicts linked to Ibn 'Arabì's doctrine. This is why it may also be included in a group of narratives that addressed this question and framed Ibn Hajar's position regarding Ibn 'Arabī's followers in the Inb $\bar{a}$ ', as illustrated in tarājim like those of Ibn al-Raddād's master, Ismāīil al-Jabartī (d. 8o6/1404), ${ }^{61}$ Aḥmad alShabakì (83o/1427), ${ }^{62}$ or strong antimonistic characters like the $q \bar{a} d \bar{\imath}$ of Zabìd Aḥmad al-Nāshirī (d. 815/1412). ${ }^{63}$ Ibn Ḥajar stated in the Inb $\bar{a}^{3}$ his admiration for al-Nāshirī, thus implicitly implying his agreement with Aḥmad al-Nāshirī's vigorous condemnation of the fasād that ensued the excessive beliefs in Ibn 'Arabī's doctrine. ${ }^{64} \mathrm{He}$ also claimed having studied with this scholar, a rather dubious assertion underlining, again, the careful shaping of a new narrative in the Inb $\bar{a}^{3}$, even about the author himself. In fact, while Ibn Ḥajar says having

\footnotetext{
59 Knysh, Ibn 'Arabī 263-9.

6o On Ibn al-Raddād's account in the 9th/15th-century Yemeni historiographical corpus, see Ahdal, Tuhfat ii, 336-7; Burayhī, Țabaqāt 299-302; Sharjī, Țabaqāt 88-91.

61 See his notice in Ibn Ḥajar, Inb $\bar{a}^{\prime}$ ii, 272-3; on Ismā̄il al-Jabartī's position on Ibn 'Arabī, see Knysh, Ibn 'Arabī 241-52; on the "Jabartī circle" in Yemen, see Mochtari de Pierrepont, Espaces i, 207-18.

62 Ibn Ḥajar, Inb $\bar{a}^{\prime}$ iv, 25.

63 Ibid. ii, 525 .

64 Ibid. 525. See also Knysh, Ibn 'Arabī 254-5.
} 


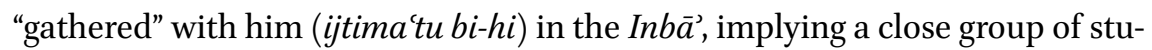
dents following the course of the teacher, in the Dhayl many years before he only claimed to have "seen" him (ra'aytu-hu), ${ }^{65}$ referring to a far more distant relationship. He also did not mention him among his Yemeni masters in his own mashyakha, included in the Raf' al-ișr. ${ }^{66}$ Yet, it may have made sense for the author to bring himself closer to Ahmad al-Nāshirī in the Inba zeal, the consistency, and the ordeals this scholar went through — being banned from Zabī and losing his position as qā doctrines $^{67}$-made him a paradigmatic illustration of the struggle against Ibn 'Arabì's followers in the first half of the 9 th $/ 15$ th century.

Thus, during al-Z̄āhir Jaqmaq's rule, when pietism and more exoteric forms of religious piety seem to have gained momentum among the ruling elites, Ibn Hajar, by association, could appear in a positive light for those who rose up against the monistic doctrine. Yet, the fact that one of his greatest masters, alFīrūzābādī, had been a defendant of Ibn 'Arabī ${ }^{68}$ a fact never explicitly pointed out by Ibn Hajar in the Inb $\bar{a}^{3},{ }^{69}$ was certainly not lost to many 'ulama $\bar{a}^{3}$ close to the doctrines of the unity of being, since al-Fīrūzābādì's sympathy for Ibn 'Arabì's doctrines was well known at this time. ${ }^{70}$

The manner in which Ibn Hajar chose to change some previous narratives written in past historiographical works can arguably be seen as a marker of the gradual need Ibn Hajar may have felt to engage or reengage in the framework of a new historiographical work designed to shape and document the political history and changes of his time. In the Inb $\bar{a}^{\prime}$, Ibn al-Raddād's example seems to fit in these new narratives, and it is likely that the Sufi master's notice may have partly served as a means to an end in regard to laying down Ibn Ḥajar's position toward Ibn 'Arabî's followers. In doing so, Ibn Ḥajar was still maintaining a balance, even at a personal level, never directly engaging with the shaykh al-akbar himself. The prominence of Ibn al-Raddād's influence in Yemen and his personal and well-known connections to the Yemeni sultans may also have been an appealing topic. After all, Ibn Ḥajar had met him, and personal testimonies

\footnotetext{
65 Ibn Hajar, Dhayl al-durar 158-9.

66 Ibn Ḥajar, Raf' al-ișr 63.

67 His critiques of and confrontation with the defendants of Ibn 'Arabī's doctrines led to his demise as qā

68 Knysh, Ibn 'Arabī 252-4; Strotman, Majd al-Dìn al-Fìrūzābādī 123, 143-55.

69 While, during Barsbāy's reign, Ibn Ḥajar clearly refers to his master's position in the Dhayl al-durar; 240 (n. 437).

70 Al-Ahdal, Tuhfat ii, 336; Aziz, Religion and mysticism 205; Strotman, Majd al-Dīn alFìrūzābādì 146, 148-9.
} 
played a relevant role to fit in the historiographical writing norms of his times. ${ }^{71}$ Moreover, such a figure allowed him to draw an implicit parallel between Ibn 'Arabì's followers' abuses and the decline and long fall of the Rasūlid Sultanate, during which the Inb $\vec{a}^{\prime}$ was written. A moral boundary, designed to prepare and train the reader to a higher form of understanding and elevation of the self (murüa), was also put forth in this short notice, echoing the roles of the literary genres of $a d a b$ and $t^{\prime}{ }^{\prime} i k h .^{72}$

\section{$5 \quad$ Ibn Ḥajar's Narrative Ambivalence and Discursive Layers}

Other examples of Ibn Hajar's ambivalent position toward Ibn 'Arabīs doctrine can be emphasized with the biographic notice of Sirāj al-Dīn al-Hindī (d. 773/1372), qā dì of the Ḥanafĩ madhhab in Cairo. ${ }^{73}$ Ibn Ḥajar noted that al-Hindī composed a commentary of al-Tä̀iyya al-kubrā (or Nazm al-sulük), a famous poem of the renowned Suf 'Umar b. al-Fāriḍ (d. 632/1235), ${ }^{74}$ celebrating mystical union ${ }^{75}$ and later closely associated with Ibn 'Arabî's monistic thought. Al-Hindī, in Ibn Hajar's words, was "strongly associated with the monistic Sufis (yata'așșabu li-l-șüfiyya al-ittihāadiyya)," and his commentary was rejected ('azara li-kalāmi-hi) by Ibn Abī Hajala (d. 776/1374), ${ }^{76}$ a prominent scholar of the Hanafi school. ${ }^{77}$ It is the only direct reference to Ibn alFāriḍ's poem in the chronicle. This close association in the narrative sequence between the subject of the notice, al-Hindī, the poem, monistic Sufis, and Ibn Abī Hajala's censorship, ${ }^{78}$ concluding immediately with a mention of al-Hindī's death, seems to orient Ibn Ḥajar's own position, as with Ibn al-Raddād's notice, toward a public opposition to Ibn 'Arabỉ's monistic theories. But ambiguity remains in the Inb $\bar{a}^{\prime}$, since Ibn Abì Hajala, the poem's censor, was also presented in the chronicle as an addictive drunk (mudmin al-khamr), ${ }^{79}$ thus casting doubt about his testimony and actions. Like with Ibn al-Raddād's notice, this anecdotic event must also be put in perspective with Ibn Hajar's personal life

\footnotetext{
71 Ibn Ḥajar, Inb $\bar{a}^{3} 1-2$.

72 Abbès, L' adab; Khalidi, Arabic 83.

73 Ibn Hajar, Inb $\vec{a}^{3} \mathrm{i}, 27$.

74 On this character, see Homerin, Arab.

75 Boullata, Verbal $15^{2}-69$.

76 Ibn Ḥajar, Inb $\bar{a}^{3} \mathrm{i}, 29$.

77 Ibid. 8o-2.

78 Ibn Abī Hajala's position seems as a whole to have been much more qualified than in Ibn Hajar's account. See Homerin, Arab 58 .

79 Ibn Ḥajar, Inb $\bar{a}^{3}$ i, 81.
} 
as he, too, like al-Hindī before him, was said to have written a partial and laudatory commentary of Ibn al-Fāriḍ's al-Tājyya. ${ }^{80} \mathrm{He}$ himself claimed in the Lissān to have recited some of Ibn al-Fāriḍ's verses to Sirāj al-Dīn al-Bulqīnī, arguably to obtain his master's opinion on the poet, who strongly condemned it. ${ }^{81}$ This leaves no doubt about Ibn Ḥajar's familiarity with the text. Ibn Hajar's personal opinion seems to have softened on this matter over the course of his life, which may also have been linked to the growing popularity of the poet as a saintly figure in Cairo.

Al-Hindī and his censor were both judged negatively, and Ibn al-Raddād's figure was presented in different shapes in the Dhayl al-durar and the Inb $\bar{a}$, underlining a qualitative modification during al-Zāhir Jaqmaq's rule to adjust the author's position on a polemical subject. These narratives illustrate Ibn Hajar's contextual ambiguity, considered both through the Inbä"s own intertextuality and the situation in which this work featured in Ibn Ḥajar's broader

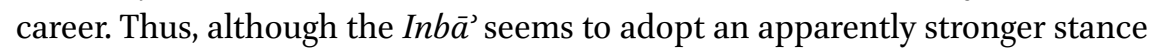
toward Ibn 'Arabī's doctrine and especially his late followers, ambivalence remains in Ibn Hajar's cautious position.

\subsection{Abü Bakr al-Mawșilï: Shaping Boundaries and New Historiographical Narratives}

However, beyond expressions of the author's stance about Ibn 'Arabï's followers in the Inb $\bar{a}^{3}$, other Sufi characters were also used to build different narratives and outline other social, political, and cultural boundaries and determine limits to Sufis' political involvement.

On this matter, it seems that asceticism, charisma, and spiritual guidance were particularly honored by Ibn Hajar, although, again, he clearly set the boundaries in which the influence of charismatic masters had to be contained. One of the most striking illustrations of this discursive construction found in the Inb $\bar{a}^{\prime}$ is the notice of Abu Bakr al-Mawșilī, one of the longest tarjamas of a Sufi character in the chronicle. Abū Bakr b. 'Abdallāh al-Mawșilī (d. 797/1394), born in Mosul, was said to be a spiritual disciple of 'Abd al-Qādir al-Jilānī. He was also a Shāfiì scholar well trained in hadìth studies and a passionate defender of the ahl al-sunna, ${ }^{82}$ praised by many 'ulama $\bar{a}^{3}$ who came to his majlis. He settled in al-Quds during the reign of al-Ẓāhir Barqūq (784-8o1/1382-99) and became a prominent Sufi shaykh of the city, at the head of the tariqa

8o Geoffroy, Soufisme 23.

81 Ibn Hajar, Lisān iv, 317-9; Geoffroy, Soufisme 354, see note 188; Homerin, Arab 58-9.

82 Geoffroy, Soufisme 86, see note 102. 
al-Mawșiliyya (or al-Shaybaniyya), that comprised two zäwiyas—one in Jerusalem and the other in Damascus. ${ }^{83}$ The following is a part of Abū Bakr's notice in the Inba :

\begin{abstract}
Abū Bakr b. 'Abdallāh al-Mawșilī, al-Dimashqī, settled in Damascus, worked with figh and the science of hadith and engaged in Sufi kaläm. He died in al-Quds in Shawwāl [797/July 1395] at the age of 6o ... Moreover, he used to mix with Sufis. He dug deeply in the science of hadith and drew out a lot [from it]. His fame spread and disciples came to him, his mention rose [steadily] and his echo resonated far. The greatest [characters] came to see him. He went on pilgrimage many times. The Sultan heard of him and praised him highly. He came to visit him in his house in al-Quds, and climbed up to him on the heights (șa'ada ilay-hi ilāal-'aliyya). [The sultan] ordered money to be given to him, and wrote him intercessions [for him to be granted positions] (shafäāat al-ḥasana), but he [always] refused. ${ }^{84}$
\end{abstract}

Most of this information, as is often the case in the In $b \bar{a}^{2}$ when the territory of al-Shām is concerned, comes from Ibn Hijjì's Ta rīk $h,^{85}$ even though Ibn H.ajar's notice presents this material in a different order and wording. It also did not include a small part on Abū Bakr al-Mawșilì's tomb, directly related to the karā$m \bar{a} t$ and the baraka attributed by Ibn Hijji to the shaykh. Such a move seems to be a recurrent feature of the Inba $\vec{a}^{3}$, the Dhayl, and the Durar, and Ibn Hajar is generally very careful when it comes to accounts of pious visits and wondrous deeds, mostly using the formula "it is said on him that (yuhkā 'an-hu)" or "it has been mentioned about him (dhukira 'an-hu)," and rarely involving himself personally.

According to Ibn Hajar's notice, Abū Bakr is a character very well considered. As a shaykh of a tariqqa, a very popular master, and a scholar trained in religious sciences, he seems to reconcile both the exoteric and esoteric nature of religious knowledge, the mastery of figh, and the spiritual accomplishment of Sufism. This figure seems to have been a rather important Sufi character in the Inb $\vec{a}$ : five characters are mentioned as his disciples and companions, which is among the highest number of connections attached to a shaykh of a tariqa. Ibn Hajar viewed him as a positive character or at the very least had a good opinion of this pious scholar. Ibn Hajar's presentation of Abū Bakr al-Mawṣilī is also significant as to the involvement of Sufi masters in defending the Sunna since

83 Geoffroy, Soufisme 181.

84 Ibn Ḥajar, Inbä' i, 497-8.

85 Ibn Hijjìi, Ta'rīkh 131 . 
Abū Bakr was "a champion of the Sunna," ${ }^{86}$ who was said to have asked his disciples to stick a paper on their foreheads bearing the inscription "Sufism and the good customs of the Prophet (al-tașawwuf wa-l-khuluq al-hanîf al-nabawì)." 87 However, this notice simultaneously underlines four specific aspects developed by Ibn Hajar: his influence upon members of the dawla; his refusal to benefit from material wealth and political and social influence using his reputation with the sultan; his mastery of exoteric sciences; and his personal qualities. It thus seems to fit in the chronicle as an elaborate way to discuss the role of charismatic leaders such as Abū Bakr al-Mawșilī, their involvement in the dynamics of power, their means of influence, their balanced commitment in the 'ulümal-dīn, and their personal deeds and moral integrity, aspects of which were illustrated by Abū Bakr al-Mawșilī's presentation in the Inb $\bar{a}$.

Later on in the chronicle, Ibn Ḥajar also mentions Abū Bakr's son Ibrāhīm (d. 814/1411): "Ibrāhīm b. Abī Bakr, al-Māhūzī, al-Dimashqī. He learned a bit of figh and followed the Sufi path with a strong religion. He had a lot of wealth and was not accepting anything from anyone. He was advising his companions against accepting any goods from anyone. In that he was following in his father's footsteps, the shaykh Abū Bakr al-Mawșilì’s path (țarīqa). People had for him an excess of belief and no amir denied his requests." ${ }^{88}$

Here, Ibrāhīm is presented in a more ambivalent manner than his father.Just as with Abū Bakr al-Mawșilī, Ibn Ḥajar insists particularly on his refusal to earn material wealth thanks to his reputation and social standing. Yet, unlike his father, Ibrāhīm is said to have used his influence upon members of the dawla, while at the same time the notion of "excess" ( $\left.z a^{\prime} i \bar{l}\right)$ is attached to the people's consideration of him. The three main elements of Abū Bakr's notice are thus presented in reverse: a poor mastery of exoteric religious science, a more negative religious and social influence, and the use of intercessions (shafā $\bar{a} t)$ from members of the dawla. This presentation emphasizes this character as a less brilliant man and scholar and underlines a generational decrease in the standing of the tarìqa, despite the moral quality recognized in Ibrāhīm. The previous mention of his father in the Inb $\bar{a}^{\prime}$ must be taken as a focal point to introduce Ibrāhim and compare him with his father. This comparison implies the slow decline of the family path and their zäwiya, embodied in the chronicle by Abu Bakr, Ibrāhīm, and the other Sufis linked to Abū Bakr al-Mawșilī. ${ }^{89}$ As such, the father and son, as Sufi masters, are used to present the positive outcome of

86 Geoffroy, Soufisme 181.

87 Ibid. 86; quoting 'Alī al-Bușrawī, Ta’rīkh 59.

88 Ibn Ḥajar, Inbä' ii, 495 .

89 Ibid. 402, 432, 457, $5^{26}$. 
Sufism in society and the boundaries that Sufi shuyükh should respect in regard to their involvement with the dawla. One would think Ibn Hajar, when it comes to Ibrāhīm, would have also been quoting Ibn Hijjì's Ta'rīkh, thus simply echoing this previous work. But Ibrāhīm's notice in the Inb $\bar{a}^{3}$ was not taken from the very nice account Ibn Hijjì's Tarīkh gives of Ibrāhīm, except for a very few elements. ${ }^{90}$ This emphasizes the fact that whereas Ibn Hajar chose to include and in some way reproduce Abū Bakr's notice, mainly from Ibn Hijjī, he also decided not to use it for Ibrāhīm, a choice implying a careful discursive strategy. In fact, these two characters seem to be mentioned in the Inba $\vec{a}$ to echo each other, since Ibrāhīm's notice only becomes meaningful for a reader after first having knowledge of his father's notice.

Both notices also fulfill a specific representation linking the tarīa alMawșiliyya, the dawla, and paradigmatic examples of Sufi shaykhs' involvement in the society and politics of the Cairo Sultanate during the end of the 8th/14th and the beginning of the 9 th/15th centuries. This is what seems to appear from the comparison with Ibn Hajar's previous works, stressing the selection Ibn Hajar made when considering the characters of his chronicle. Indeed, the discursive space accorded to Abū Bakr and his son is unmatched in his other works.

Thus, in the Durar al-kāmina, Abū Bakr al-Mawșilī is only presented as follows: "Abū Bakr b. 'Abdallāh al-Mawṣilī, settled in Damascus and died in alQuds in 797, aged 6o."91

As for his son, he is not mentioned in either the Durar al-kämina or the Dhayl al-durar, even though Ibn Hajar, when writing these two works, was already using Ibn Hijjì's Ta'rīkh. ${ }^{92}$ Abū Bakr al-Mawșilì's notice in the Durar and Ibrāhīm's absence from Ibn Hajar's previous historiographical works show that, in the 83os/1430s, these characters were almost meaningless as to the historiographical representation the author was then shaping. Yet, Abū Bakr al-Mawșilī was quite famous in Damascus, and it is doubtful that Ibn Ḥajar had no information about him. ${ }^{93} \mathrm{He}$ had been dead for more than 40 years, but his name was still renowned in the 830s/1430s, and his țariqa was still relevant in the social environment of Damascus and al-Quds. ${ }^{94}$ The fact that the Inb $\vec{a}^{2}$

\footnotetext{
90 The 19 times he accomplished the hajj (2o times in Ibn Ḥajar's Inb $\left.\bar{a}^{3}\right)$. See Ibn Hiijjī, Ta'rīkh 970.

91 Ibn Ḥajar, Durar i, 261 (n. 1187).

92 Ibn Ḥajar does quote Ibn Hijjì's Ta’rīkh in the Durar, whose writing may have started in 83o, two years before the Dhayl. 'Izz al-Dīn, Ibn Hajar 273.

93 Ibn Qāọī Shuhba, Tảrīkh 559-6o.

94 Sakhāwī, al-Daw’i i, 36; Dhayl 473.
} 
awarded this new place to Abū Bakr al-Mawșilī and his son illustrates a new representation Ibn Hajar wanted to introduce in his chronicle.

Abū Bakr al-Mawșilī’s example illustrates how using one historiographical work of Ibn Ḥajar to document a Sufi character mentioned in the Dhayl aldurar, the Durar, or the Inb $\bar{a}^{\prime}$ would be meaningless without recontextualizing these works, for they would mainly refer to a precise and contextualized moment of Ibn Hajar's mindset and shaping of history. This representation may also be why he chose to remain silent regarding the very strong influence Abū Bakr was said to have had on Sultan al-Ẓāhir Barqūq, ${ }^{95}$ such relationships not being in service of the paradigmatic example he was emphasizing with Abu Bakr's representation and behavior to produce a meaning going beyond the character's narrative.

\section{$6 \quad$ Ibn Ḥajar's Chronicle and the Production of a Contextualized Social Order}

Following these examples, it appears that it is not the doctrines and ideas that the author focused on when presenting his characters in the $\operatorname{In} b \bar{a}^{3}$, it is rather a set of public behaviors that he described and to which he attributed personal, legal, and moral opinions. As such, it seems it is the irruption in the public space of practices, ideas, and behaviors deemed unorthodox or morally reprehensible and the subsequent disruption of the public order that seem to be Ibn Hajar's main concern in displaying these narratives, echoing his personal position as faqīh and chief $q \bar{a} \underline{a} \bar{i}$. Since the social context in which the author was living and his personal situation changed, he also integrated new narratives into his previous historiographical works, and he transformed previously written ones. But beyond that, the relation between the author and the normative cultural and social framework he was shaping allows us to question the implicit meaning produced by Ibn Hajar concerning references to Sufi characters. Indeed, his concern for public order may be why he redefined his position vis-à-vis the Yemeni Sufi shaykh Ibn al-Raddād and his followers and why he may have negatively exposed Ibn 'Arabi’s followers for their excesses but not the shaykh al-akbar himself. Other cases hint to similar dynamics. Following the growing success of the Suhrawardī Sufi master Muhammad al-Ghamrī (d. 849/1446) ${ }^{96}$ and his construction of a jāmi ic in the market of Amīr Juyūsh in Cairo, Ibn Ḥajar

95 Geoffroy, Soufisme 86, see note 102.

96 On this character, see Garcin, Histoire 290-1. 
wrote to him to move elsewhere; the 'ulam $\bar{a}^{3}$ had reproached al-Ghamrī for this construction and the preaching that ensued in the market (fa-áa 'alay-hi ahl al-ilm).${ }^{97}$ Yet, Ibn Hajar made no personal statement regarding al-Ghamri's beliefs. He only expressed concern for the question of the mosque in the $s \bar{q} q$, namely, raising an issue related to the occupation and use of urban spaces. The same pattern of subtle distinction emerges in the case of the Hurüfiyya. The tariqa al-Hurūifyya ${ }^{98}$ was an esoteric order deemed by some contemporaries as going mostly against the usual accepted religious practices and beliefs of the time. ${ }^{99}$ As already pointed out by O. Mir-Kasimov, Ibn Hajar explained to his audience the strange ideas of their original founder, the Persian Faḍl Allāh b. Abī Muḥammad al-Astarabādī al-Tabrīzì (d. 796/1394). ${ }^{100}$ Yet, he waited to really engage in the chronicle with the followers of the Hurūfiyya only when they appeared as disturbing the public order in the Cairo Sultanate in 820/1417. There, he reminded his audience of the burning of the Hurüfiyya's writings, and at this point, he condemned the Hurūfi followers harshly.101

The concern for the disruption of the social order may also help to explain the chronicle's specific discursive production linked to the Suf tariqas and the way they were introduced. As we have mentioned above, țariqas were rarely referred to in the Inb $\vec{a}$. Yet, some mentions concerning them still touch upon the same concern of maintaining social, religious, and cultural normative stability. The way Ibn Hajar mentioned the Wafāiyya order, an offshoot of the Shādhiliyya, is one of these cases. ${ }^{102}$ When he presented the leader of the Wafāiiyya, the Sufi shaykh 'Alī b. Muhammad Wafā', he introduced him in a rather positive light, mentioning that he had met with him. But he was famously shocked by the excessive manner in which the muridin of the shaykh testified of their respect and belief in their master: the disciples prostrated (alsujüd) themselves in front of him. ${ }^{103}$ The author felt constrained to leave the room in front of such blameworthy behavior. He felt that this public display of excessive reverence was beyond acceptable boundaries.

Following from this careful attention in the Inba $\vec{a}$ to public and normative behaviors, one may better understand why most members of the Shādhiliyya

\footnotetext{
97 Ibn Ḥajar, Inb $\bar{a}^{\prime}$ iv, 243 .

98 Also called al-Nasīmiyya or al-Nu'aymiyya, from the founder Faḍl Allāh Nu'aymī's disciple, 'Imād al-Dīn al-Nasimī. See Mir-Kasimov, Takfïr and messianism 193-4, 197. In the Inbä', the Ḥurūfĩ shaykh of Aleppo is called Nasīm al-Dīn al-Tabrīzī. He was killed in 820/1417. Ibn Ḥajar, Inbä’ iii, $136-7$.

99 Mir-Kasimov, Takfir 195-6.

$100 \quad$ Ibid. 196.

101 Ibn Ḥajar, Inbä’ iii, $136-7$.

102 On this țariqa, see McGregor, Sanctity.

103 Ibn Ḥajar, Inbä’ ii, 308; Geoffroy, Soufisme 307; McGregor, Sanctity 55.
} 
were introduced positively in the $\operatorname{In} b \bar{a}$. The Shādhiliyya was a more discreet and private path, mostly confined to dedicated spaces of private religious practice. ${ }^{104}$ By far and large - with the exception of the taríqa's branches that went, in some forms, according to Ibn Hajar, astray, like the Wafāiiyya-the Shādhiliyya presented no risk of disturbing either the religious and cultural normative framework of the Cairo Sultanate's society or the public order that Ibn Hajar, as a $q \bar{a} d \bar{l} \bar{i}$ was bound to uphold.

The Inb $\bar{a}^{\prime}$ thus displayed various situations in which forms of the practice of tasawwuf were sometimes determined as having a reprehensible footprint on society, power, or religion. As such, one could not claim that the Sufi environment introduced in the $I n b \bar{a}^{3}$ was expressed in a rather negative or positive way, an antagonism far too caricatural. Nor did Sufism form a specific topic in the Inb $\vec{a}$. Sufi characters and Sufism — as a body of legitimate and recognized spiritual and religious paths and practices-were part and parcel of the much broader social order presented in the chronicle.

In that regard, recent studies have sometimes dismissed the very contextualized and ideological perspectives set in the medieval narratives of Sufi display, not always taking into account the specific goals and framework of the sources used in their studies. One of the most recent milestones addressing the question of medieval Sufis in the Middle East, Nathan Hofer's The popularisation of Sufism, thus uses an impressive array of historiographical narratives to display, in very interesting ways, the role and agency of Sufis in the widespread success of Sufism from the late 6th/12th century to the early 8th/14th century. Yet, using sources ranging from before Ibn Khallikān's (d. 681/1282) masterpiece Kitāb wafayāt al-a'yānn up until after al-Suyūtī's (d. 911/1505) short history of Mișr, ${ }^{105}$ going through al-Udfuwì's (d. 799) Țāli ${ }^{106}$ and its shaping of the Șa'īd regional history, the Cairo Shāfi'ì, Ash'arī, 8th/14th-century master al-Subkī $(\mathrm{d} .771 / 1370)^{107}$ or the 9 th/15th-century great historian al-Maqrīzì (d. 845/1442), ${ }^{108}$ it does not majorly address the metatextual narrative environment upon which the study's main arguments are grounded. Differences among the sources and the authors, in historical context, cultural and social environment, institutional positions, political and theological differences, and various individual and collective experiences regarding mysticism, create a narrative framework that would have been worth investigating to better grasp the

\footnotetext{
104 Geoffroy, Soufisme 172.

105 Suyūṭ̄, Husn al-mu'ādara fì akhbār mir wa-l- qāhira.

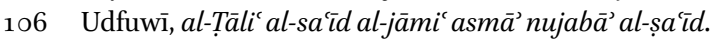

107 Subkī, Țabaqāt al-shāfi iyya al-kubrā.

108 Maqrīzì, Al-Muqaffā l-kabīr.
} 
agency of Sufis in the success of various forms of Sufi practices, discourses, and institutions. The position of Sufism and Sufis in their social and cultural environment evolved in various ways at different stages of the Cairo Sultanate history, along with tasawwuf-oriented discourses and discourses on Sufis and their reception. The very insertion of Sufi narratives in the historiographical framework of the Cairo Sultanate was in that respect part of a wider, dynamic, and contextualized exchange set for various literary, scholarly, political, and ideological needs and a changing audience.

The display of Sufis and Sufism in Ibn Hajar's narrative was echoing various strata of meaning that also bear witness to Ibn Hajar's evolving environment and contextual changes. When the disruption of a current social and political order was at play, a moral or legal condemnation was likely to be expressed by Ibn Hajar. Such a judgment could echo with much strength because Ibn Hajar's status, as a scholar of considerable reputation and fame, had become an embodiment of the social and legal order he was narratively representing. Most of the time, though, mentions of Sufism were completely integrated into the normative framework of the chronicle's events and narration, which may have been precisely one of the desired narrative outcomes of the Inb $\vec{a}$ : to create a historical narrative reference framework, much more likely to be listened to, read, and discussed, that was based on Ibn Hajar's personal shaping of his own times. For that reason, the author's self-representation and personal agency in the chronicle's events appear not only as a feature of the Inb $\bar{a}^{3}$ but as a powerful narrative tool. It reinforced both the authenticity of the narratives, upheld the strength of their representation, and boosted Ibn Hajar's own standing. Thus, while the author's personal testimonies could add strength to the validity of the historical events he was unfolding, the events were also chosen to display the author's opinions, including on a wide variety of legal, social, religious, and cultural questions, in which matters related to Sufism and Sufi practices were sometimes included.

In that regard, the Inb $\bar{a}^{3}$ was definitely building a new perspective as to Ibn Hajar's own historiographical positions and assertive opinions, and while shaping new memories, it was also consciously erasing or omitting some. His last historiographical work thus crafted a new historical narrative that Ibn Hajar felt was best serving both his personal interests at the time and the Cairo Sultanate's needs for a narrative of the social order, an order in which Ibn Hajar may have felt either himself, Jaqmaq's regime, or his broader audience were ideologically better integrated. 


\section{Bibliography}

\section{Manuscripts}

al-Biqā̄ī, Ms 'Arabiyya akhbār 40 fols $106^{\mathrm{v}}-7^{\mathrm{r}}$.

\section{Primary Sources}

al-Ahdal, Tuhfat al-zaman fi ta'rīkh al-Yaman, ed. 'A. al-Hibshī, 2 vols., Beirut 1986. al-Burayhī, Ṭabaqāt șulaḥā’ al-Yaman, ed. 'A. al-Ḥibshī, Sanaa 1983. al-Bușrawī, Ta’rīkh al-Bușrawī, ed. A.Ḥ. al-'Alabī, Damascus 1987. Ibn al-Dayba', Qurrat al-'uyūn bi-akhbār al-Yaman al-maymūn, ed. M. al-Akwa', Sanaa 2006.

Ibn al-Dayba', Bughyat al-mustafìd fì akhbār madīnat Zabìd, ed. 'A. al-Hibshī, Sanaa 2006.

Ibn Ḥajar al-'Asqalānī, Lisān al-Mìzānn, 6 vols., Hyderabad 1911-3.

Ibn Ḥajar al-'Asqalānī, Inbä' al-ghumr bi-abnä' al-'umr fi-l-ta'rīkh, ed. Ḥ. Ḥabashī, 4 vols., Cairo 1968-72.

Ibn Ḥajar al-'Asqalānī, Dhayl al-durar al-kāmina fí a yyān al-mìa al-thāmina, ed. 'A. Darwìsh, Cairo 1992.

Ibn Ḥajar al-'Asqalānī, Durar al-kāmina fì a yān al-mìa al-thāmina, ed. S. al-Karnakawī, 5 vols., Beirut 1993.

Ibn Ḥajar al-'Asqalānī, Raf' al-Ișr 'an quẹāt Miṣr, Cairo 1998.

Ibn Hijjì, Ta'rīkh Ibn Hijjī, ed. 'A. al-Kundarī, Beirut 2003.

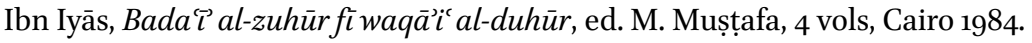

Ibn Qaḍi Shuhba, Ta’rīkh Ibn Qāḍ̄ Shuhba, ed. 'A. Darwish, 4 vols., Damascus 1994.

Ibn Taghrī Birdī, Nujūm al-zāhira fì Mulūk Mișr wa-l-Qāhira, 16 vols., Cairo 1963.

Ibn Taghrī Birdī, Manhal al-șāfıı wa-l-mustawfı́ ba'da al-wāfı̀, ed. M. Amīn, 7 vols., Cairo 1993.

al-Sakhāwī, al-Daw' al-lāmi' li-ahli al-qarni al-tāsi', 12 vols., Beirut 1992.

al-Sakhāwī, Dhayl al-tām 'alā duwal al-islām li-l-Dhahabì, ed. H.I. Marwa, Beirut 1992. al-Sakhāwī, al-Jawāhir wa al-durar fì tarjama shaykh al-Islām Ibn Hajar al-'Asqalānī, Beirut 1999.

al-Sharjī, Ṭabaqāt al-khawāșș ahl al-șidq wa-l-ikhlāṣ, ed. 'A. al-Ḥibshī, Beirut 1986, Sanaa ${ }^{2} 1992$.

\section{Secondary Sources}

Behrens-Abouseif, D., Cairo of the Mamluks: A history of the architecture and its culture, London 2007.

Blecher, Hadith commentary in the presence of students, patrons, and rivals: Ibn Hajar and Șahīh al-Bukhārī in Mamluk Cairo, in Oriens 41 (2013), 261-87.

Boullata, I.J., Verbal arabesque and mystical union: A study of Ibn al-Farid's "Al-Taciyya al-Kubra," in ASQ 3 (1981), 152-69. 
Broadbridge, A., Academic rivalry and the patronage system in fifteenth-century Egypt: Al-'Aynī, al-Maqrīzī, and Ibn Hajar al-'Asqalānī, in MSR 3 (1999), 85-107.

Geoffroy, É., Le soufisme en Egypte et en Syrie sous les derniers Mamelouks et les premiers Ottomans: orientations spirituelles et enjeux culturels, Damascus 1995.

Geoffroy, É., Ṭā'ifa, in $E I^{2}, \mathrm{x}, 1116-7$.

Garcin, J.C., Histoire et hagiographie de l' Egypte musulmane à la fin de l'époque mamelouke et au début de l'époque ottomane, in Hommages à la mémoire de Serge Sauneron, 1927-1976, ii, Egypte post-pharaonique, Cairo 1979, 287-316.

Gharaibeh, M., Brokerage and interpersonal relationships in scholarly networks. Ibn Hağar al-'Asqalānī and his early academic career, in S. Conerman (ed.), Everything is on the move: The Mamluk empire as a node in (trans-)regional networks, Bonn 2014, 223-68.

Gharaibeh, M., Narrative strategies in biographical dictionaries: The ad-Durar alKāmina of Ibn Hajar al-'Asqalānī-A case study, in S. Conerman (ed.), Mamluk historiography revisited -Narratological perspectives, Göttingen 2018, 51-76.

Hirschler, K., Medieval Arabic historiography: Authors as actors, London 2006.

Hofer, N., The popularisation of Sufism in Ayyubid and Mamluk Egypt, 1173-1325, Edinburgh 2015.

Homerin, Th.E., From Arab poet to Muslim saint: Ibn al-Färid, his verse, and his shrine, Cairo 1994, 2001 (rev. ed.).

'Izz al-Dīn, K.M., Ibn Hajar al-'Asqalānī mu'arikh, Beirut 1987.

Jacques, R.K., Ibn Hajar al-'Asqalani, Oxford 2009.

Kawash, S.K., Ibn Hajar al-'Asqalāni (1372-1449 A.D.): A study of the background, education, and career of a 'älim in Egypt, Princeton University 1969.

Khalidi, T., Arabic historical thought in the classical period, New York 1994.

Knysh, A.D., Ibn Arabî, Ibn 'Arabi in the later Islamic tradition: The making of a polemical image in medieval Islam, New York 1999.

Mayeur-Jaouen, C., Al-Sayyid al-Badawî, un grand saint de l'islam égyptien, Cairo 1994.

McGregor, R.J.A., Sanctity and mysticism in Medieval Egypt: The Wafa Sufi order and the legacy of Ibn 'Arabi, New York 2004.

Mir-Kasimov, O., Takfïr and messianism: The Ḥurūfī case, in C. Adang et al. (eds.), Accusations of unbelief in Islam: A diachronic perspective on takfir, Leiden 2015.

Mochtari de Pierrepont, Z., Espaces sacrés et lignages bénis dans la Tihāma médiévale yéménite: sociétés, religions et pouvoirs, Université Paris I Panthéon Sorbonne, 2 vols., Paris 2018.

Petry, C.F., The civilian elite in the later middle ages, Princeton 1981.

Raḥmānī, A.A., The life and works of Ibn Hajar al-'Asqalānī, Dhaka 2000.

Strotmann, V., Majd al-Dìn al-Fìruzābādì (1329-1415): A polymath on the eve of the early modern period, Leiden 2016. 
Tillier, M., Vies des cadis de Mișr, 237/851-366/976. Extrait du Raf' al-Ișr 'an quḍāt Mișr d'Ibn Hajar al-Asqalānī, Cairo 2002.

Trimingham, J.S., The Sufi orders in Islam, Oxford 1971.

Vallet, É., L'Arabie Marchande: État et Commerce sous les Sultans Rasûlides du Yémen (626-858/1229-1454), Paris 2010.

Van Steenbergen, J., Mamlukisation between social theory social practice, in S. Conerman (ed.), ASK Working Papers 22 (2015) 1-44.

Van Steenbergen, J., Appearances of dawla and political order in late medieval SyroEgypt. The state, social theory, and the political history of the Cairo Sultanate (thirteenth-sixteenth centuries), in S. Conermann (ed.), History and society during the Mamluk period (1250-1517): Studies of the Annemarie Schimmel Research College II (MaS 12), Bonn 2016.

Van Steenbergen, J., P. Wing and K. D'hulster, The Mamlukization of the Mamluk Sultanate? State formation and the history of fifteenth century Egypt and Syria: Part I: Old problems and new trends, in History Compass 14 (2016), 549-69. 